Viso - Cadernos de estética aplicada Revista eletrônica de estética

ISSN 1981-4062

No 17, jul-dez/2015

http://www.revistaviso.com.br/
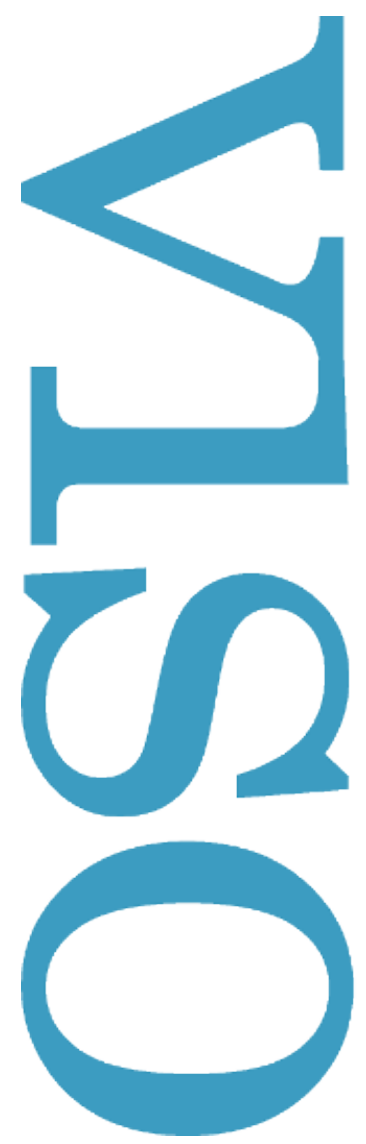

\title{
Variações experimentais: um estudo sobre a narrativa em A trégua, de Primo Levi \\ Pedro Caldas
}

Universidade Federal do Estado do Rio de Janeiro (UniRio)

Rio de Janeiro, Brasil 


\section{RESUMO}

Variações experimentais: um estudo sobre a narrativa em $A$ trégua, de Primo Levi

Este artigo pretende contribuir com a discussão sobre a narrativa a partir de uma leitura de A trégua, de Primo Levi. Publicado em 1963, A trégua é o segundo livro de Primo Levi, concluído dezesseis anos após É isto um homem?, e traz uma questão inquietante: por um lado, o livro, ao contar a história do retorno de Primo Levi para sua casa, em Turim, após ser libertado do campo de concentração de Auschwitz, é também uma narrativa de reencontro com a própria humanidade; por outro lado, o autor, no final, admite sua angústia ao reconhecer que o mal de Auschwitz permanecerá para sempre com ele. Portanto, o que muda? Como contar uma narrativa que não elabora uma mudança essencial, mas episódios possivelmente aleatórios? Neste sentido, proponho o conceito de uma narrativa estruturada a partir de "variações experimentais" em torno à experiência de trégua. Formulação retirada de uma das mais marcantes caracterizações do livro, o menino Hurbinek, em cujo nome Levi testemunha, as "variações experimentais" podem ser compreendidas como uma alternativa ao impasse acima entre episódios expressivos e sua relativa incapacidade de gerar alguma mudança significativa no sentido histórico do Holocausto.

Palavras-chave: Homero - Ulisses - narrativa - ardil - perseverança 


\section{ABSTRACT}

\section{Experimental variations: A Study of Narrative in Primo Levi's The Truce}

This article seeks to contribute to the discussion of narrative based on a reading of The Truce, by Primo Levi. Published in 1963, The Truce is Levi's second book. It was finished 16 years after If This is a Man, and deals with a disquieting issue: on the one hand, by narrating the story of Levi's return home in Turin after being liberated from the Auschwitz concentration camp, it is also a narrative of the reencounter with one's own humanity; on the other hand, in its final lines, Levi admits his anguish as he recognizes that the evil of Auschwitz will remain with him forever. What changes, then? How can one possibly narrate a story without elaborating on an essential transformation, but, instead, by describing seemingly random episodes? In this regard, I propose here the concept of a narrative that is structured based on "experimental variations" around the truceexperience. I borrow this formulation from one of the most striking descriptions of the book - about the boy child Hurbinek, on whose behalf Levi testified. These "experimental variations" can be understood as an alternative to the above-mentioned impasse between expressive episodes and the relative inability to produce a significant change in the historical meaning of the Holocaust.

Keywords: Primo Levi - The Truce - Narrative - Testimony 
CALDAS, P. "Variações experimentais: um estudo sobre a narrativa em $A$ trégua, de Primo Levi". In: Viso: Cadernos de estética aplicada, v. IX, n. 17 (jul-dez/2015), pp. 133-147.

DOI: 10.22409/1981-4062/v17i/209

Aprovado: 09.12.2015. Publicado: 27.02.2016.

(C) 2016 Pedro Caldas. Esse documento é distribuído nos termos da licença Creative Commons Atribuição-NãoComercial 4.0 Internacional (CC-BY-NC), que permite, exceto para fins comerciais, copiar e redistribuir o material em qualquer formato ou meio, bem como remixá-lo, transformá-lo ou criar a partir dele, desde que seja dado o devido crédito e indicada a licença sob a qual ele foi originalmente publicado.

Licença: http://creativecommons.org/licenses/by-nc/4.0/deed.pt BR

Accepted: 09.12.2015. Published: 27.02.2016.

(C) 2016 Pedro Caldas. This document is distributed under the terms of a Creative Commons Attribution-NonCommercial 4.0 International license (CC-BY-NC) which allows, except for commercial purposes, to copy and redistribute the material in any medium or format and to remix, transform, and build upon the material, provided the original work is properly cited and states its license.

License: http://creativecommons.org/licenses/by-nc/4.0/ 
Há cerca de três anos, quando já me preparava para a pesquisa que comecei há poucos meses, li, pela primeira vez no original, La Tregua, de Primo Levi. Não era o meu favorito dele: preferia, sem ter maiores dúvidas a respeito, É isto um homem? e, sobretudo, Os afogados e os sobreviventes. Mas, após a leitura, estava tocado pela beleza da obra. Ainda sem a preocupação analítica, sem a atenção necessária que nos faz anotar, fichar e rabiscar trechos que podem nos ajudar a elaborar uma questão apresentada no dito projeto e a escrever um artigo ou uma conferência, fiquei com a impressão, meio esfumaçada, meio contemplativa, de ver em $A$ trégua um livro sobre "a retomada da vida". Ficara na minha memória uma passagem que falava de qualquer coisa como poder novamente pisar a grama, a terra, algo tão simples, mas que transmitia uma experiência de reconciliação com o mundo. Agora, já com a preocupação de sublinhar as passagens que poderão ser úteis para eventuais e sempre frágeis comprovações de "hipóteses", não dependo mais de minha memória e posso citá-la letra por letra.

Havia caminhado por horas no ar maravilhoso da manhã, aspirando-o, como se fosse um remédio, até o fundo de meus pulmões arruinados. Não conseguia me manter muito firme sobre as pernas, mas sentia uma necessidade imperiosa de retomar posse de meu corpo, de restabelecer o contato, perdido há quase dois anos, com as árvores e a grama, com a terra firme e escura com a qual se podia sentir crescer as sementes, com o oceano de ar que transportava o pólen das árvores, onda a onda, dos Cárpatos até as ruas enegrecidas da cidade minerária. ${ }^{1}$

Escolhi este trecho porque ele ficara em minha lembrança. Há outros igualmente tocantes e que, ao contrário deste, falam não somente do reencontro com o próprio corpo e com a natureza, mas com outros seres humanos, personagens imperfeitos, engraçados, absolutamente amáveis. Galina é uma das minhas favoritas, uma jovem russa "[...] camponesa, esperta, ingênua, [...] não particularmente culta, não particularmente séria" 2 mas em que "se sentia operar a virtude, a mesma dignidade de seus companheiros-amigos-namorados, a dignidade de quem trabalha e sabe o porquê, de quem combate e sabe que tem razão, de quem tem a vida pela frente" ${ }^{\text {, }}$, uma figura que, ao se despedir de Levi na hora de retornar para a sua casa, "desaparece, sugada pela vacuidade do espaço russo e pelos caminhos de seu país imenso, deixando atrás de si um perfume acre de terra, de juventude e de alegria". ${ }^{4}$

Há muitos outros trechos comoventes (pelo menos para mim) em A trégua. Por exemplo: me encantara a imagem de Levi sentir em si um ar que, ao entrar e sair de seus pulmões, o liga, mesmo frágil, a algo mais amplo, a todo um mundo, a pessoas como Galina, tirando-Ihe da solidão mas dando-lhe uma medida discreta de um pequeno homem em meio às imensas paisagens do leste europeu.

O que pode haver de significativo em lembranças tão imprecisas de uma leitura, como disse, contemplativa e satisfeita com a própria fruição do estilo de Levi? Suspeito, sem ter certeza, de que a construção da autoimagem como um elo muito sutil, mas, ainda assim, um elo capaz de manter uma conexão com o mundo e com os homens. Mas é só 
uma suspeita. De toda forma, este elenco de personagens anônimos e singulares (em algumas vezes, Levi sequer Ihes dá os nomes, provavelmente por jamais tê-los sabido) também pode nos seduzir, e, assim, nos sentimos quase redimidos por sua graciosidade e aliviados com o esperado retorno à casa do narrador e, sobretudo, com a restauração de uma (auto)imagem positiva da humanidade.

Mas, admirado com a grande coleção de figuras caracterizadas por Levi, ainda não notara a moldura que permitia vê-las, e que organizava as coordenadas de minha contemplação. Isto só viria depois, quando, por obrigação da pesquisa, tornei a abrir as páginas de $A$ trégua, desta vez com as preocupações e os procedimentos habituais de uma pesquisa: ler com lápis na mão, anotando, fichando, classificando, e, sobretudo, tendo na memória a leitura recente de É isto um homem?, sem a qual talvez deixasse passar em brancas nuvens o dado irrelevante apenas na aparência de que, apesar de dezesseis anos se colocarem entre um livro e outro, $A$ trégua começa exatamente no momento em que Primo Levi pusera o ponto final em É isto um homem?. O cenário é o mesmo, mais precisamente em Buna-Monowitz, um dos campos do complexo concentracionário de Auschwitz, e o dia também, o dia 27 de janeiro de 1945, recordado por Primo Levi com muita precisão:

Assim, para nós, a hora da liberdade soou grave e circunspecta, e encheu a nossa alma, ao mesmo tempo, de alegria e de um doloroso senso de pudor. [...] e de pena também, porque sentíamos que [...] nada mais de bom e puro poderia acontecer que viesse a cancelar o nosso passado, e que os sinais da ofensa permaneceriam em nós para sempre, nas lembranças daqueles que os viram, nos lugares onde ocorreram e nas narrativas que fôssemos fazer deles [...] é estupidez imaginar que a justiça humana extinga a ofensa. Ela é uma fonte inexaurível do mal. ${ }^{5}$

Se colocarmos estas duas passagens em sequência, isto é, se, no início, o narrador sente "a presença inexaurível do mal" para depois sentir o ar em seus pulmões, podemos ter a impressão de que $A$ trégua tenha uma estrutura linear. Não é bem assim. Sim, os capítulos, em grande parte, narram uma história com início, meio e fim bem definidos, mas precisamos ter cuidado: a linearidade cronológica não se confunde com uma reconciliação do ser humano consigo mesmo (ou de sua autoimagem idealizada). Afinal, as últimas páginas do livro nos censuram esta imagem de sossego. Cito um trechinho da reconstrução que Levi faz do momento em que chega na Itália: "dos seiscentos e cinquenta que éramos ao partir, retornamos em três. E quanto perdemos de nós mesmos, nestes meses? Que coisa haveríamos de reencontrar em casa? O quanto de nós foi corroído, apagado?". ${ }^{6}$ As perguntas permanecem abertas, e, no que diz respeito às certezas, Primo Levi parece ter somente uma: "sentíamos fluir pelas veias, juntamente com o sangue contaminado, o veneno de Auschwitz". ${ }^{7}$ Não posso deixar de notar uma certa semelhança com o que Levi diz logo no primeiro capítulo: "nada de bom e puro pode cancelar o nosso passado". Nem mesmo pessoas como Galina. O corpo do qual se começa a sentir como próprio ao andar sobre a grama carrega, dentro de si, nas veias, o veneno de Auschwitz. Os seres humanos conhecidos no caminho de volta não 
substituem os companheiros perdidos nos últimos meses. Então, o que significa este retorno para casa, o que significa continuar a vida, quando o veneno dos campos ainda corre nas veias? O que terá mudado após a libertação do campo? Nada? Então, por que contar histórias, algumas tristes, outras encantadoras, testemunhadas ao longo de todo o percurso de nove meses de volta para casa? Seria $A$ trégua uma narrativa que não conta nenhuma mudança, que apenas confirma a "presença inexaurível do mal"? O que há neste livro que já não estivesse, portanto, em É isto um homem?. Pensar um pouco nesta pergunta significa, sobretudo, pensar sobre o valor da narrativa, da continuidade da história, da continuidade da própria vida.

As páginas de $A$ Trégua, aparentemente uma coleção de casos, trazem um problema teórico interessante para as discussões sobre a narrativa, sobretudo, se lembrarmos que a função desta é "[...] constituir o significado de uma mudança. O interesse e mesmo o fascínio apresentados pelas histórias consiste [...] na coerência que se concede ao que apenas parecia díspar e desconectado". ${ }^{8}$ Quando a mudança mesmo é posta em dúvida, qual seria o significado da passagem do tempo entre a saída do Lager (a casa dos mortos) e a chegada em Turim (a casa da família)? Mas, por outro lado, se a mudança é motivo de questionamento, o mesmo dificilmente se poderia dizer do fascínio e do interesse. Fica a questão. A melhor saída, a meu ver, é tentar compreender este fascínio, sobretudo, para que ele não se confunda com a simples reafirmação de uma imagem confortante da humanidade.

A trégua não seduz por entreter - afinal, o narrador acabara de sair de um campo de concentração - mas por envolver, isto é, por não oferecer uma perspectiva segura, criada de fora, que nos dê coordenadas externas de leitura e compreensão. Estas coordenadas estão dadas no livro, e aí fico preso ao sentido literal de envolvimento, de enredamento, de estar em uma situação inescapável. O episódio inesquecível, portanto, é mais do que ilustrativo. É formativo. Este é um primeiro passo para compreendermos a atração de $A$ trégua, e admito que ainda tento elaborar e entender o encantamento, dar um passo além do que, a princípio, fora uma impressão de "retomada da vida". E é dentro desta malha que Levi justifica a narrativa de $A$ trégua. A justificativa poderia ser identificada no registro de seu encontro com Hurbinek, que está no segundo capítulo do livro, quando Levi, mesmo já liberto, ainda está no Lager. Quem leu A trégua dificilmente se esquece de Hurbinek, "o filho da morte, o filho de Auschwitz". ${ }^{9}$ Para quem ainda não o leu, algumas palavras sobre esta criança: é um menino de cerca de três anos, paralisado dos rins para baixo, e que, apesar da idade, ainda não havia conseguido pronunciar uma palavra. Não tinha mais pai e mãe, mortos no campo, e seu nome fora dado por aqueles que o cercavam de cuidados. A descrição de Levi é das mais impressionantes: "seus olhos vivos estavam cheios de vontade de libertar-se, de romper a tumba do mutismo [...] a palavra que Ihe faltava [...] saltava de seu olhar, com urgência explosiva: era um olhar humano e animal". ${ }^{10}$ Gostaria de destacar duas expressões desta descrição: "romper com a tumba com o mutismo" e a "urgência explosiva do olhar humano e animal", em um lugar indefinido, de fronteira, algo que ainda faz ressoar o questionamento do livro 
anterior: é isto um homem? Somos submetidos a um olhar do qual não podemos escapar, no qual já estamos implicados e no qual nos espelhamos e, talvez por isto mesmo, "era um olhar [...] que nenhum de nós conseguia suportar, de tal forma era pleno de força e pena". ${ }^{11}$ Considero decisivo o que Levi diz sobre o impacto do olhar de Hurbinek, e aqui me lembro do que Jeanne-Marie Gagnebin escreve em um artigo chamado exatamente "Palavras para Hurbinek": em meio a uma profusão de representações sobre o Holocausto, "[...] que desemboca num sentimento de obscenidade, opor-se-ia um olhar que não busca o gozo do espetáculo [...] um olhar que acolhe a interrogação suscitada por um encontro". ${ }^{12}$ Isto é decisivo: os encontros que nos interrogam. E estas interrogações podem ser uma pista para a razão da escrita de $A$ trégua.

Preso na tumba do mutismo, Hurbinek já não fica tão só justamente por capturar os outros com o olhar. Mas, finalmente, Hurbinek fala. Não uma palavra articulada, compreensível em outra língua: "qualquer coisa como Mass-klo, ou matisklo"13, lembra-se Primo Levi. E o trecho a seguir pode, de alguma maneira, nos ajudar a tentar entender como fazer falar o "filho da morte, o filho de Auschwitz", e, assim, rompermos não somente a tumba do mutismo, mas dos chamados "limites da representação".

Do canto de Hurbinek vinha, de vez em quando, uma palavra. Não exatamente a mesma, claro, mas certamente era uma palavra articulada: ou melhor, palavras articuladas de maneira sutilmente diversa, variações experimentais em torno a um tema, a uma raiz, talvez a um nome. ${ }^{14}$

Variações experimentais. O caminho de volta para casa também é uma grande variação experimental: não é reto, linear, nem garantido, e, por vezes, não se sabe exatamente onde se está (em torno a um tema, uma raiz, um nome). Mas o esforço de Hurbinek poderia ser entendido como o esforço de Levi: "Nada resta dele. Ele testemunha pelas minhas palavras". ${ }^{15}$ Se o traço da existência de Hurbinek fora o esforço da fala, ou, ainda, o olhar insuportável, e se o livro tenta substituir este "filho de Auschwitz", um produto exclusivo dos campos de concentração, não seria mais o caso de compreender a narrativa de volta à casa como uma luta por romper, com variações experimentais, a tumba do mutismo, ou seja, da solidão? O testemunho é mais do que uma homenagem sentimental. É um método: não são somente palavras para Hurbinek. Quem testemunha é Hurbinek, por meio de Levi. E Hurbinek faz variações experimentais. Proponho uma leitura de $A$ trégua como uma série de variações experimentais. Falar por Hurbinek? Sim. Mas também falar como Hurbinek: Mass-klo, Matisklo... Variações experimentais. Em torno a que, a quem? Diria: à experiência de trégua, à vivência que adquire forma nos inúmeros episódios do livro. Penso, no momento, em três possibilidades de variação.

Vamos à primeira: em uma entrevista dada já no final de sua vida, Levi disse que a incapacidade de entender as ordens berradas em alemão foi uma das principais causas da morte de italianos em campos de concentração: "o isolamento linguístico, naquelas condições, era mortal. Quase todos os italianos foram mortos por isto. Porque, do 
primeiro ao último dia, não entendiam as ordens, e isto não era admitido [...]". ${ }^{16}$ Mas, em A trégua, é notável como a incompreensão linguística foi capaz de gerar alguns dos episódios mais divertidos do livro. Um deles ocorre nas imediações de Stáryjie Doróghi (atualmente localizada na Bielorrússia), onde Levi fica por bastante tempo, a ponto de chegar a entediar-se. ${ }^{17}$ Daí a necessidade de manter contato com os russos, ainda que "com sucesso escasso". ${ }^{18}$ Mas a dificuldade linguística, embora quase intransponível, não tinha os efeitos fatais e as dimensões traumáticas do Lager. Um bom exemplo é um soldado com quem Levi se encontra quando se dirige a um riacho, onde buscará água para cozinhar batatas. O russo está no mesmo lugar pelas mesmas razões, mas falta-lhe o fogo. Levi o ajuda, dando-lhe um graveto aceso. O russo o olha espantado. E a razão do espanto do soldado se revela rapidamente: "[...] percebeu que eu não falo russo. $\mathrm{O}$ fato de um homem, adulto e normal, não fale russo, ou seja, não fale, parece-lhe uma atitude insolente, como se eu recusasse abertamente responder-lhe". ${ }^{19}$

Mas, ao contrário do que muito provavelmente ocorreria no Lager, as consequências não são terríveis. Levi nota rapidamente o que poderia ser entendido como uma inversão em relação ao comportamento habitual dos alemães, ainda que não faça esta comparação no texto, e comenta sobre o comportamento do soldado: "Não está mal-intencionado, ao contrário: está disposto a me ajudar, a reerguer-me de minha culpável condição de ignorância: o russo é tão fácil, todos falam russo, até mesmo as crianças que ainda não sabem andar". ${ }^{20} \mathrm{E}$ começa a ensiná-lo, mesmo que sem método, a pronunciar "batata", "fogo"...

O episódio é mais do que anedótico. Sob um certo ponto de vista, Levi é colocado em uma situação análoga à de Hurbinek, ou seja, na do esforço do aprendizado a falar em condições desfavoráveis. Ainda mais do que isso: aprender a falar em uma circunstância babélica.

Já temos uma variação experimental: a variação em torno do tema da incomunicabilidade, pois o que se mostrara fatal em É isto um homem? torna-se cômico em $A$ trégua, sem que fosse cancelada a experiência da incomunicabilidade. Mas no trechinho em que Levi fala de Hurbinek não há somente o esforço para romper "a tumba do mutismo". Havia chamado a atenção para uma outra característica de Hurbinek que, a meu ver, Levi incorpora na narrativa do livro: o olhar humano e animal. Esta poderia ser uma outra variação experimental.

Assim como a incomunicabilidade é um tema de É isto um homem? e A trégua, a fronteira entre o humano e o animal, ou, para ser mais amplo, entre o humano e o natural, é tema presente nas duas obras. As metáforas com o mundo da natureza, a meu ver, são frequentemente utilizadas em É isto um homem? para ativar a imaginação do leitor, dando-Ihe uma dimensão palpável dos horrores dos campos de concentração. Um exemplo forte se encontra na definição do prisioneiro Null Achtzehn, cuja vida foi totalmente esvaziada antes de ir para a câmara de gás, e que é descrito da seguinte 
maneira: "[...] quando fala, quando olha, [Null Achtzehn] dá a impressão de estar internamente oco, nada além de um invólucro, como certos despojos de insetos que encontramos na beira dos pântanos, ligados por um fio às pedras e balançados pelo vento". ${ }^{21}$ Mas em $A$ trégua as metáforas com a natureza se tornam recursos expressivos para falar de uma vitalidade primordial. Logo em suas primeiras páginas, ainda em Birkenau, encontramos o retrato de Noah, que fora o Scheissminister em Auschwitz, o ministro das latrinas que passeava com sua carroça por todo o campo, cantando a plenos pulmões, recolhendo os baldes com as imundícies produzidas por todos os presos. Apesar do ofício amargo, vemos um homem que é, ele mesmo, um sinal de recomeço. Enquanto fazia o seu serviço, sempre encontrava um tempo para encontros amorosos nas barracas femininas. Noah, "[...] pássaro de alto voo, cruzava, do amanhecer até de noite, por todas as estradas do campo, a bordo se seu carro repugnante", e era "[...]amigo de todos os homens e de todas as mulheres. O dilúvio acabara: no céu negro de Auschwitz Noah via resplandecer o arco-íris, e o mundo era seu, a ser repovoado". ${ }^{22} \mathrm{~A}$ casca do inseto morto dá lugar à ave de alto voo.

Mas, além de notar outra função para o uso da metáfora, faço questão de sublinhar a expressão "repovoado". Afinal, o mundo havia sido aniquilado. Não há como esquecer da sentença de Levi ao recordar o enforcamento do último homem em Monowitz, um dos momentos mais agudos de $E$ isto um homem?: "destruir o homem é difícil, tanto quanto criá-lo: não foi fácil, não foi rápido, mas vocês, alemães, vocês o conseguiram". ${ }^{23} \mathrm{Em} A$ trégua não deixa de ser uma narrativa da reação ao "gênio da contracriação" ${ }^{24}$ dos nazistas:

[...] o mundo em torno a nós parecia ter retornado ao caos primigênio, e borbulhava de exemplares humanos [...] defeituosos, anormais; e cada um destes se agitava, em movimentos cegos e deliberados, no afã da busca da própria sede, da própria esfera, como poeticamente se narra, nas cosmogonias dos antigos, sobre as partículas dos quatro elementos. ${ }^{25}$

Portanto, assim como não se cancelara a incomunicabilidade em Auschwitz, também não o fora a fronteira entre o humano e o natural. Elas são reapresentadas em $A$ trégua, mas como um encontro entre partículas elementares, o encontro entre Levi e o soldado, entre Noah e suas amantes. A trégua é um livro que pode ser lido como uma narrativa das origens, como uma cosmogonia muito específica, uma cosmogonia pós-apocalíptica que foi belamente definida quando Levi se recorda de um episódio ocorrido no campo de parada de Katowice. Nele, o narrador partilha conosco a reação dos soldados russos (eles mais uma vez) quando sabem que retornarão para casa.

A guerra estava para acabar, a longuíssima guerra que havia devastado o seu país; para eles, a guerra já havia acabado. Era a grande trégua: pois ainda [...] não havia sido pronunciado o nome nefasto da Guerra Fria. Estavam alegres, tristes e cansados, e se compraziam no vinho e na comida, como os companheiros de Ulisses quando puxavam as naus para as praias. ${ }^{26}$ 
Mais uma vez a presença de uma alusão a um mito (não exatamente de origem, mas de retorno às mesmas ${ }^{27}$ ) é significativa. A trégua não é um recomeço que apaga o passado, que simplesmente "segue em frente", como se fosse possível se distanciar com segurança do passado, mas antes uma narrativa de recomeço que carrega baldes de excrementos.

Mas ainda haveria, pelo menos, uma terceira variação experimental. Quem se recorda bem de É isto um homem? tem grandes chances de se lembrar do sonho no qual Primo Levi imagina o seu retorno à casa. Relembro-o aqui e o partilho com aqueles que ainda não conhecem o livro:

Aqui estão minha irmã, algum amigo que não consigo identificar, e muitas outras pessoas. Todos estão me escutando [...] é um prazer intenso, físico, inexprimível, estar na minha casa, entre pessoas amigas, e ter tanta coisa para contar: mas não posso deixar de notar que os meus ouvintes não me acompanham. Na verdade, estão absolutamente indiferentes: conversam confusamente entre si, como se eu não estivesse ali. Minha irmã me olha, se levanta e se retira sem dizer palavra. ${ }^{28}$

O aspecto terrível do sonho não está somente na incapacidade de falar (de Hurbinek, por exemplo), mas na dificuldade em ser ouvido, e, assim, podemos pensar tanto em um limite da escuta, da recepção, como habitualmente mencionamos o da representação. ${ }^{29}$

Este é um tema ainda presente em $A$ trégua, e, para elaborá-lo, será necessário antes falar de Mordo Nahum, "o grego", cujo caráter é tão forte que reivindica para si todo um longo capítulo. É um personagem que, ao cruzar seu caminho com o de Primo Levi, fica na memória do narrador, e, mesmo que fiquemos anos sem reler $A$ trégua, uma história inofensiva somente na aparência muito provavelmente ficará também estampada na memória do leitor. É a história do sapato. Da importância de se ter sapatos. Como assim? "Ele [o grego] me explicou", diz Levi, "que ficar sem sapatos é coisa muito grave". E continua com a lição aprendida com o grego:

Quando há guerra, é necessário pensar antes de tudo em duas coisas: em primeiro lugar, nos sapatos, em segundo, na comida; e não vice-versa, como acredita o vulgo: porque quem tem sapatos pode sair em busca de comida, enquanto o contrário não vale. - Mas a guerra acabou - objetei: e a considerava acabada, como muitos a consideravam naqueles meses de trégua ${ }^{30}$, e em um sentido muito mais universal do que se ousaria pensar hoje. - Guerra é sempre, - respondeu memoravelmente Mordo Nahum. ${ }^{31}$

Ora, se "Guerra é sempre", o que poderia aprender com $A$ trégua que já não soubéssemos em É isto um homem?. Mas, tendo, de um lado, este diálogo, e, de outro, a leitura ainda recente de $E$ isto um homem? e de breves textos de Levi escritos exatamente entre o período de seus dois primeiros livros, foi impossível, para mim, deixar de notar uma curiosa inversão no significado histórico de Auschwitz. Dou como exemplo um artigo de apenas duas páginas publicado em 1955 por Levi em uma revista de Turim, que, por ocasião dos dez anos de liberação dos campos e fim da Guerra, 
decidiu editar um número especial sobre o assunto. No seu texto, Levi, à época bem menos lido do que viria a ser em breve, critica o silêncio em torno ao genocídio. Para ele, não se calavam somente os algozes, mas também aqueles que "[...] solicitados ou forçados a exprimir um juízo, tentam, de todo modo, desviar-se da discussão, e passam a falar de armas nucleares, bombardeios indiscriminados, dos processos de Nuremberg,

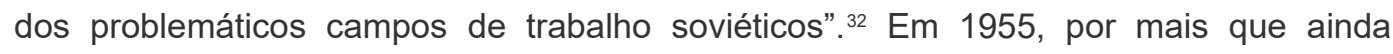
acontecessem guerras, haveria um caráter de tal forma extraordinário nos horrores do fascismo que levava todos aqueles que, mesmo sensivelmente tocados por atrocidades diversas do século XX, diluíam a conversa em generalidades quando o assunto passava a ser Auschwitz.

Agora prefiro chamar a atenção para a ideia de trégua conforme destaquei no trecho citado mais acima. Sim, o grego parece mesmo ter razão: Guerra é sempre. Na breve reprodução do diálogo entre Levi e Mordo Nahum, questões que até hoje atiçam as discussões sobre a narrativa de um evento-limite como o Holocausto. ${ }^{33}$ Para um, o Lager fora um "desvio monstruoso, uma anomalia [...] na minha história" ${ }^{34}$; para outro, "uma triste confirmação de coisas notórias". ${ }^{35} \mathrm{~A}$ partir da experiência do primeiro, o Lager é um evento excepcional e rompe qualquer chance de se construir uma continuidade entre 0 ontem, o hoje e o amanhã. Em seu lugar, um pavoroso intervalo seguido de meses de recuperação da humanidade demolida; já a partir da vivência do segundo, temos uma estrutura constante e sem rachaduras.

O mais importante é que o pesadelo de Levi lembrado em É isto um homem? reaparece em $A$ trégua, mas desta vez como experiência real, vivida no mercado de Katowice, na Polônia, onde Levi encontra um advogado capaz de compreender francês e alemão que conte a todos o que acabara de passar nos campos de concentração. Mesmo sem saber a língua local, Primo Levi percebe que o advogado escondia dos ouvintes sinceramente interessados o fato de ele ser judeu, apresentando-o como um preso político. Indagado por um Levi ofendido e espantado sobre a razão da ocultação de sua verdadeira identidade, o advogado responde em francês: "c'est mieux pour vous. La guerre n'est pas finie".

Ora, exatamente as palavras do grego, como nota imediatamente Primo Levi, que sentiu "[...] a onda quente do sentir-se livre, do sentir-se humano entre humanos, do sentir-se vivo, fluir para longe de mim [...]". ${ }^{36}$ Ou seja: ele volta a ser preso, volta a um passado recente que ele julgara haver sido deixado para trás ao perceber que os ouvintes haviam compreendido o que havia para ser dito, e foram-se embora lentamente. E complementa: "qualquer coisa do gênero havia sonhado nas noites de Auschwitz: de falar e não ser ouvido, de reencontrar a liberdade e continuar sozinho". ${ }^{37}$

Os episódios do grego e do advogado polonês mostram que as variações experimentais são, de fato, aleatórias e abertas, pois reapresentam um passado recente e doloroso, mas não necessariamente esta reapresentação possuirá uma modulação cômica, que 
pressupõe um relativo afastamento de um passado que, se não pode ser cancelado, ao menos poderia ser visto sob outra perspectiva. O passado é mais indomável do que parece, e a narrativa, por mais que atribua sentido e forma, não possui plenos poderes de escolha e arbítrio, e, por isto, pode se fazer absolutamente presente. O que os episódios do advogado e do grego nos mostram é que o presente também não pode ser cancelado. Se a viagem entre o centro da Polônia e o norte da Itália não é linear, pois chega a passar pelos confins da Bielorrússia, o mesmo vale para o caminho entre o passado e o futuro: a esperança por uma viagem tranquila de volta é confundida com uma esperança por um mundo melhor e restabelecido. Mas Levi sabe que nada é tão simples: "era uma esperança ingênua, como todas que repousam sobre cortes muito límpidos entre o bem e o mal, entre o passado e o futuro". ${ }^{38}$

Concluo refazendo a pergunta: o que muda, então? Uma melhor maneira de terminar este estudo talvez seja a de relembrar a moldura do livro: os primeiros capítulos de $A$ trégua ainda se passam em Auschwitz, mas uma mudança já se expressa em meio ao horror deixado pela destruição alemã: o despertar da sensibilidade, ou, para ser mais exato, dos sentidos. Não há como deixar de se impressionar com o que Levi diz a respeito da alteração de sua capacidade de perceber o mundo ao seu redor. Em sua primeira noite como homem livre: "[...] no meu ano de Buna vi desaparecerem quatro quintos de meus companheiros, mas não havia jamais sentido a presença concreta, o assédio da morte". ${ }^{39}$ Quem tem bem fixa na memória a leitura de É isto um homem? poderá concordar que estas palavras têm um peso, pois a terrível peculiaridade da morte no Lager estava não somente em seu caráter sistemático, frio e planejado, em seu caráter moderno, mas, sobretudo, porque ela era - aprendemos com Primo Levi sequer temida pelas vítimas totalmente exaustas e esvaziadas pelo cotidiano de trabalho, fome e frio: "se hesita a chamar de morte a sua morte, perante a qual eles não sentem medo porque estão cansados demais para compreendê-la". ${ }^{40}$ Portanto, me parece muito expressivo o título do primeiro capítulo de $A$ trégua: o degelo. Estamos em janeiro de 1945, e o rigoroso inverno polonês ainda teria dois meses à frente; portanto, o degelo do título não dizia respeito a um fenômeno natural, mas a um fenômeno humano. Era uma capacidade de sentir o mundo e sentir a si mesmo que estava perdendo uma camada, tornando-se mais acessível a tudo, inclusive à morte. Antes de pisar a grama e sentir o ar que se espalha pelo leste europeu, ele narra uma experiência igualmente sensível, mas diversa, quando entra em um dos barracões do campo já liberto de Birkenau:

Era uma centena de beliches, a metade, pelo menos, ocupada por cadáveres hirtos de frio [...] Não havia nenhum tipo de aquecimento, com exceção dos hálitos infectados dos cinquenta doentes que viviam ainda. Apesar do gelo, o mau cheiro das fezes e da morte eram tão intensos que impediam a respiração, sendo preciso forçar os próprios pulmões para obrigá-los a receber aquele ar viciado [...]

Arrastei-me tateando ao longo de um dos corredores, por entre beliches de três andares, tropeçando e cambaleando, às escuras, no estrato de excrementos gelados. ${ }^{41}$ 
Esta passagem minha memória seletiva não havia guardado em um primeiro momento. Mas agora fica evidente o paralelismo com a primeira: o ar oferecido aos pulmões é outro; e os pés caminham sobre matéria menos agradável. Outras dores reivindicariam seu sentimento: "a dor do exílio, da casa distante, da solidão, dos amigos perdidos, da juventude perdida, e da multidão dos cadáveres ao meu redor". ${ }^{42}$ Mas algo já era sentido, assim como a solidão sentida em Auschwitz também não é cancelada, mas reaparece no sentimento de luto pelos companheiros que ficaram pelo caminho.

* Pedro Caldas é professor adjunto do Departamento de História da UniRio.

* Este texto é o resultado de pesquisas desenvolvidas com financiamento do CNPq (Bolsa em Produtividade de Pesquisa).

${ }^{1}$ LEVI, P. La Tregua. Torino: Einaudi, 1997, p. 124.

2 Ibidem, p. 75.

${ }^{3}$ Ibidem, p. 124.

${ }^{4}$ Ibidem.

${ }^{5}$ Ibidem, p. 11.

${ }^{6}$ Ibidem, p. 252.

7 Ibidem.

${ }^{8}$ LIMA, L. C. A aguarrás do tempo: Estudos sobre a narrativa. Rio de Janeiro: Rocco, 1989, pp. 6061.

${ }^{9}$ LEVI, P. Op. cit, p. 22.

${ }^{10}$ Ibidem.

11 Ibidem, p. 22.

12 GAGNEBIN, J.-M. "Palavras para Hurbinek". In: SELIGMANN-SILVA, M.; NESTROVSKI, A. (orgs.) Catástrofe e Representação. São Paulo: Escuta, 2000, p. 106.

${ }^{13}$ LEVI, P. Op. cit, p. 23.

${ }^{14}$ Ibidem.

${ }^{15}$ Idem, p. 24.

${ }^{16}$ Cf. CAMON, F. Conversazione con Primo Levi: se c'è Auschwitz, può esserci Dio? Parma: Ugo Guanda Editore, 2014 (1ª. ed. 1997), p. 39.

${ }^{17}$ LEVI, P. Op. cit, p. 189.

18 Ibidem, p. 190.

19 Ibidem, p. 191.

${ }^{20}$ Ibidem.

${ }^{21}$ LEVI, P. [1958]. Se questo è un uomo. Edição comentada por Alberto Cavaglion. Torino: Einaudi, 2012, p. 61. 
${ }^{22}$ LEVI, P. La Tregua. Op. cit., p. 31.

${ }^{23}$ LEVI, P. Se questo è un uomo. Op. cit., p. 130.

${ }^{24}$ LEVI, P. La Tregua. Op. cit., p. 146.

${ }^{25}$ Ibidem, p. 36.

${ }^{26}$ Ibidem, p. 66.

${ }^{27}$ Aqui entendo origem como "casa", isto é, como a Ítaca de Ulisses. Um outro tema também reapresentado em $A$ trégua é o próprio Ulisses, que aparece em É isto um homem?, ainda que, neste, seja o Ulisses dantesco, e não o homérico.

${ }^{28}$ LEVI, P. La Tregua. Op. cit., p.49.

29 Para quem desejar tomar conhecimento das discussões sobre o assunto no campo historiográfico, ver: FRIEDLÄNDER, S. (org.) Probing the limits of representation: Nazism and "The Final Solution". Cambdrige (MA); London: Harvard University Press, 1996 (3ª ed.).

${ }^{30}$ Grifo meu.

${ }^{31}$ LEVI, P. La Tregua. Op. cit., p. 57.

32 LEVI, P. "Anniversario". In: Cosí fu Auschwitz. Testimonianze 1945-1986. Con Leonardo de Benedetti. OrgAnização de Fabio Levi e Domenico Scarpa. Torino: Einaudi, 2015, p. 52.

${ }^{33}$ Uma boa introdução para a discussão do problema da excepcionalidade do Holocausto e sua relação com a concepção de continuidade histórica pode ser encontrada em: KERSHAW, I. The Nazi Dictatorship: Problems \& Perspectives of Interpretation. London: Arnold, 2000 (4ª ed.), Cap.9. Para a definição de evento-limite, ver a explicação de Saul Friedländer: "o que torna a 'solução final' em um evento-limite é o próprio fato de ser [...] a tentativa deliberada, sistemática, industrialmente organizada e largamente bem-sucedida de exterminar todo um grupo humano no meio da sociedade ocidental". Cf. FRIEDLÄNDER, S. "Introduction". In: FRIEDLÄNDER, S. (org.) Probing the limits of representation. Op. cit.

${ }^{34}$ LEVI, P. La Tregua. Op. cit., p. 58.

${ }^{35}$ Ibidem.

${ }^{36}$ Ibidem, p. 61.

${ }^{37}$ Ibidem.

${ }^{38}$ Ibidem, p. 41.

${ }^{39}$ Ibidem, p. 14.

${ }^{40}$ LEVI, P. Se questo è un uomo. Op. cit., p. 78.

${ }^{41}$ LEVI, P. A trégua. São Paulo: Companhia das Letras, 2010, pp. 112-113. Optei por citar a tradução por não conseguir encontrar termos melhores em português para o trecho traduzido por Marco Lucchesi.

${ }^{42}$ LEVI, P. La Tregua. Op. cit., p. 14. 